Tạp chí Các Khoa học về Trái Đất, 37 (3), 284-288

Viện Hàn lâm Khoa học và Công nghệ Việt Nam
Tạp chí Các Khoa học về Trái Đất
Website: http://www.vjs.ac.vn/index.php/jse

\title{
Conference
}

\section{International Union of Geodesy and Geophysics}

\author{
Nguyễn Văn Giảng \\ Viện Vật lý Địa cầu, Viện Hàn lâm Khoa học và Công nghệ Việt Nam
}

\section{TÓM TÁT}

Liên hiệp Hội Vật lý Địa cầu và Trắc địa quốc tế (IUGG) là tổ chức khoa học phi chính phủ được thành lập từ năm 1919. IUGG là một trong 32 liên hiệp hội khoa học quốc tế hiện nay. Việt Nam là một thành viên chính thức của IUGG và có cơ cấu tổ chức theo qui chế của một liên hiệp hội quốc gia do Viện Hàn lâm Khoa học và Công nghệ Việt Nam là cơ quan chủ quản và Viện Vật lý Địa cầu là cơ quan chủ trì. Đại hội đồng IUGG được tổ chức thường kỳ 4 năm một lần và lần thứ 26 vừa được tổ chức thành công ở Praha, Cộng hòa Séc. Đại diện cho Việt Nam tham dự lần này là Viện trưởng Viện Vật lý Địa cầu - TS. Nguyễn Xuân Anh. Bài viết này xin trích giới thiệu về tổ chức IUGG và nội dung nghị quyết của Đại hội đồng lần thứ 26 để đọc giả của Tạp chí có thêm thông tin về phương hướng và kế hoạch các hoạt động của liên ngành khoa học này.

@2015 Vietnam Academy of Science and Technology

\section{About IUGG}

International Union of Geodesy and Geophysics (IUGG) is a non-governmental, scientific organization, established in 1919. IUGG is one of the 32 scientific Unions presently grouped within the International Council for Science (ICSU). IUGG is dedicated to the international promotion and coordination of scientific studies of Earth (physical, chemical, and mathematical) and its environment in space. These studies include the shape of the Earth, its gravitational and magnetic fields, the dynamics of the Earth as a whole and of its component parts, the Earth's internal structure, composition and tectonics, earthquakes and elastic wave propagation, the generation of magmas, volcanism and rock formation, the hydrological cycle including snow and ice, all aspects of the oceans, the atmosphere, ionosphere, magnetosphere and solar-terrestrial relations, and analogous problems

Email: giangnv@igp-vast.vn associated with the Moon and other planets. IUGG encourages the application of this knowledge to societal needs, such as mineral resources, mitigation of natural hazards and environmental preservation. IUGG is comprised of eight semiautonomous Associations, each responsible for a specific range of topics or themes within the overall scope of Union activities. In addition, IUGG establishes inter-Association Commissions, and relationships with several other scientific bodies with similar interests. IUGG holds General Assemblies at four-year intervals, and each of its Associations organize Scientific Assemblies as well as topical symposia in the intervening period between General Assemblies. IUGG is committed to the principle of free exchange of data and knowledge among nations, and encourages unreserved scientific participation by all peoples. The official languages of the Union are French and English.

\section{Associations of the IUGG}

These eight International Associations are: 


\section{N.V. Giảng/Tạp chí Các Khoa học về Trái Đất, Tập 37 (2015)}

- International Association of Cryospheric Sciences (IACS)

- International Association of Geodesy (IAG)

-International Association of Geomagnetism and Aeronomy (IAGA)

-International Association of Hydrological Sciences (IAHS)

-International Association of Meteorology and Atmospheric Sciences (IAMAS)

-International Association for the Physical Sciences of the Ocean (IAPSO)

-International Association of Seismology and Physics of the Earth's Interior (IASPEI)

-International Association of Volcanology and Chemistry of the Earth's Interior (IAVCEI)

Inter-Association Commissions and Working Groups

The Associations are free to convene their own General Assemblies and to sponsor particular Symposia, often in partnership with one another, and, like the Union, are managed by a Bureau and Executive Committee whose members are elected during their General Assemblies. Within its own discipline each Association is responsible for determining its own programme of investigations and for supporting the activities of its own component parts.The numerous Symposia and Workshops organized by the Associations, together with the General Assemblies, provide the opportunity for geodesists and geophysicists from the majority of the countries of the world to discuss their respective methodologies, results and hypotheses and to plan collaborative research projects.The Symposia are intended to be particularly helpful to the younger scientists from the developing countries of the world. The IUGG has made special financial provision for them to participate in the Symposia organized under the aegis of the Union and its Associations.

\section{Scientific Assemblies of the Associations}

\subsection{IUGG General Assemblies}

Each National Committee for Geodesy and Geophysics, which functions as a non- governmental entity in its relations with IUGG, is represented at General Assemblies of the Union by Delegates appointed by its Adhering Body. During these assemblies, policies governing the Union are agreed on, research programmes requiring international participation are formulated and coordinated and plans are drawn for their execution. The scientific results of programmes in progress are discussed at the numerous Scientific Symposia, Commission and Working Group meetings and other gatherings of scientists that are held during these assemblies. General Assemblies have been held since 1922 and, since 1963, at 4 years intervals. The last General Assembly was held in Prague, Czech Republic in 2015.

IUGG General Assemblies

\begin{tabular}{|c|c|c|c|}
\hline Assembly, Year & National & Foreigners & Total \\
\hline \multicolumn{4}{|l|}{ Rome, 1922} \\
\hline \multicolumn{4}{|l|}{ Madrid, 1924} \\
\hline \multicolumn{4}{|l|}{ Prague, 1927} \\
\hline Stockholm, 1930 & 91 & 240 & 331 \\
\hline Lisbon, 1933 & 40 & 160 & 200 \\
\hline Edinburgh, 1936 & 80 & 264 & 344 \\
\hline Washington, 1939 & 580 & 225 & 805 \\
\hline Oslo, 1948 & 46 & 322 & 368 \\
\hline Brussels, 1951 & 60 & 858 & 918 \\
\hline Rome, 1954 & 163 & 760 & 923 \\
\hline Toronto, 1957 & 293 & 872 & 1165 \\
\hline Helsinki, 1960 & 121 & 1254 & 1375 \\
\hline Berkeley, 1963 & 1124 & 814 & 1938 \\
\hline Zurich, 1967 & 151 & 2049 & 2200 \\
\hline Moscow, 1971 & 1070 & 1507 & 2577 \\
\hline Grenoble, 1975 & 413 & 2151 & 2564 \\
\hline Canberra, 1979 & 469 & 1475 & 1944 \\
\hline Hamburg, 1983 & 495 & 2709 & 3204 \\
\hline Vancouver, 1987 & 539 & 3400 & 3939 \\
\hline Vienna, 1991 & 162 & 4169 & 4331 \\
\hline Boulder, 1995 & 2066 & 2415 & 4481 \\
\hline Birmingham, 1999 & 647 & 3405 & 4052 \\
\hline Sapporo, 2003 & 1989 & 2162 & 4151 \\
\hline Perugia, 2007 & 618 & 3757 & 4375 \\
\hline Melbourne, 2011 & 675 & 2717 & 3392 \\
\hline
\end{tabular}

Prague, 2015

The $26^{\text {th }}$ General Assembly of the International Union of Geodesy and Geophysics was held from June 22 to July 2, 2015 in Prague, the Czech Republic. The meeting was characterized by the central theme: "Earth and Environmental Sciences for Future Generation". Over 4200 participants from 90 countries and regions from all five 
Tạp chí Các Khoa học về Trái Đất, 37 (3), 284-288

inhabited continents gathered in the historical and beautiful city of Prague and in 11 days could fully enjoy the rich and inspirational scientific as well as social program. Almost 5400 contributions out of more than 5700 submissions were presented (more than 2200 as posters) in a total of 202 symposia and workshops, divided into 639 sessions. It is good to know that the financial budget of the meeting was able to fully or partly support the attendance of 619 participants, mainly young scientists from countries of need. The Local Organizing Committee and the Scientific Programme Committee want to express their sincere thanks to all who actively helped to organize this meeting.

\section{Next IUGG General Assembly Montreal, Canada (July 8-19, 2019)}

Candidates for the IUGG Bureau and Finance Committee (2015-2019)

The IUGG Nominating Committee selected the candidates named in the list for consideration for the election of the IUGG officers at the 26th IUGG General Assembly in Prague, Czech Republic.

President: Michael Sideris (Canada, IAG)

Vice-President: Kathy Whaler (UK, IAGA)

Secretary General: Alik Ismail-Zadeh (Germany/Russia, IASPEI)

Treasurer : Aksel W. Hansen (Denmark, IAMAS)

IUGG General Assemblies Resolutions adopted by the Council at the $26^{\text {th }}$ General Assembly:

\section{Resolution 1: Role of Ocean in Climate}

The International Union of Geodesy and Geophysics

Considering: The important role of the ocean in the whole Earth system, in particular its interactions with the atmosphere, at all time-scales;

Acknowledging: That this fact must be properly translated into modeling, either for operational oceanography or for study of the Earth climatic system and that the use of these models for estimating relevant states (past, present or future) requires specific observations; Quantities related to physical oceanography are of fundamental importance for research related to biological or environmental aspects of the ocean (for instance ocean acidification and deoxygenation) or for societal impact (sea level);

Noting: The recommendations from recent international conferences;

Urges: All countries to contribute through international cooperation and coordination to establish adequate and sustainable observing systems, ensuring high quality observations of the ocean on long time scales; Relevant international organizations such as the Intergovernmental Oceanographic Commission (IOC) and the Group on Earth Observations (GEO) to work together to reach the previous objectives;

Resolves: To continue and amplify national and international research efforts on the proper modeling of the ocean in climatic systems and to contribute fully to societal investigations related to this topic.

Resolution 2: Future Satellite Gravity and Magnetic Mission Constellations

Considering: The interest and need of the IUGG scientific community to understand processes of global mass transport in the Earth system, and the interaction among its subsystems including continental hydrology, cryosphere, atmosphere, ocean and solid Earth, in order to close the global water budget and to quantify the climate evolution of the Earth; The long lead time required to bring an earth observation system into operation;

Acknowledging: The experience acquired in the last decade within the IUGG in analyzing data from dedicated satellite missions such as CHAMP, GRACE, GOCE and Swarm for the purpose of estimating the gravity and magnetic fields and their time variations; The clear expression of need from the user communities so far, and the definition of joint science and user requirements for a future satellite gravity field mission constellation by an international working team under the umbrella of IUGG;

Noting: The need for a long-term sustained observation of the gravity and magnetic fields and related mass transport processes of the Earth beyond the lifetime of GRACE and the GRACE 


\section{N.V. Giảng/Tạp chí Các Khoa học về Trái Đất, Tập 37 (2015)}

Follow-On planned for the 2017 - 2022 period, and beyond the lifetime of Swarm, currently 2013 to 2018; The demonstrated need for satellite constellations to improve temporal and spatial resolution and to reduce aliasing effects;

Urges: International and national institutions, agencies and governmental bodies in charge of supporting Earth science research to make all efforts to implement long-term satellite gravity and magnetic observation constellations with high accuracy that respond to the aforementioned need for sustained observation.

\section{Frame \\ Resolution 3: Global Geodetic Reference}

Considering: The significant efforts of the International Association of Geodesy in developing and maintaining fundamental geodetic products for scientific and societal benefits, in particular through its Global Geodetic Observing System (GGOS); The achievements realized by the UN Global Geospatial Information Management (GGIM) through its Working Group on Global Geodetic Reference Frame (GGRF), in which IUGG played a significant role through its International Association of Geodesy;

Recognizing: The adoption in February 2015 by the General Assembly of the United Nations of a resolution entitled "A Global Geodetic Reference Frame for Sustainable Development".

Urges: The UN GGIM GGRF Working Group to engage with the IUGG and other concerned organizations such as the Committee of Earth Observation Satellites (CEOS) and the Group on Earth Observations (GEO), in order to promote the implementation of the UN GGIM GGRF RoadMap;

Resolves: To support the implementation of the intent of the UN resolution.

Resolution 4: Real-Time GNSS Augmentation of the Tsunami Early Warning System

Considering: That large populations may be impacted by tsunamis generated by megathrust earthquakes; That among existing global real-time observational infrastructure, the Global Navigation Satellite Systems (GNSS) can enhance the existing tsunami early warning systems;

Acknowledging: The need to coordinate with the UNESCO Intergovernmental Oceanographic Commission (IOC) and the established intergovernmental coordination framework to define GNSS network requirements, data sharing agreements and a roadmap for the development and integration of the GNSS tsunami early warning augmentation;

Urges: Operational agencies to exploit fully the real time GNSS capability to augment and improve the accuracy and timeliness of their early warning systems; That the GNSS real-time infrastructure be strengthened; That appropriate agreements be established for the sharing of real-time GNSS data within the tsunami early warning systems; Continued support for analysis and production of operational warning products;

Resolves: To engage with IUGG member states to promote a GNSS augmentation to the existing tsunami early warning systems; Initially to focus upon the Pacific region because the high frequency of tsunami events constitutes a large risk to the region's large populations and economies, by developing a prototype system, together with stakeholders, including scientific, operational, and emergency responders.

\section{Resolution 5: Geo-Energy Resources}

Considering: The challenges posed to our planet by climate change, and the international efforts to transition in the next decades towards a low-carbon economy with the aim to limit the global warming to within $2^{\circ} \mathrm{C}$ with respect to the 1850-1900 average;

Noting: The crucial role of new renewable energy and electricity sources for the future energy strategy and climate change control; The invaluable contribution that science can bring to develop scenarios and identify new technologies and solutions enabling the required transition to a low-carbon economy; The challenges posed by the global exploitation of geo-resources, including issues such as induced/triggered seismicity, environmental contamination, and resource supply;

Recognizing: The Future Earth initiative of the International Council for Science; The unique 
Tạp chí Các Khoa học về Trái Đất, 37 (3), 284-288

competence of IUGG in climate change consequences as well as renewable geo-resources fundamental for the future energy supply, including hydropower, wind and geothermal energy, and to study scientifically the challenges and risks associated with the exploitation and extraction of new renewables sources of energy and electricity.

Urges: International and national institutions, agencies and governmental bodies to support scientific advancement and new knowledge development in the field of geo-resources;

Resolves: To promote and coordinate scientific contributions needed to limit the impact of climate change and enable the transition to a future lowcarbon economy, and to adopt a holistic view covering all aspects from geo-resources to consequences and risks.

\section{Resolution 6: Geoscience Cooperation}

Noting: The increasingly cross-disciplinary nature of geoscience research means that fields that once were distinct now overlap in interests; That many important problems in geosciences require the integration of geodesy, geology, geophysics, and other geoscience fields; That the IUGG and other geoscience unions are able to serve as a focal point for many of these common interests; That the International Union of Geological Sciences has suggested exploring the possibility of organizing a joint geoscientific assembly;

Resolves: To enhance cooperation and exchange with the other geoscience unions by expanding the formation of joint working groups or commissions; To explore the organization of a joint geoscientific assembly.

\section{Resolution 7: International Scientific Activities and Cooperation}

Considering: That opportunities to undertake, evaluate, and apply international scientific research on environmental extremes and their associated impacts useful to society are growing, necessitating and justifying increased support in order to provide maximum benefits for society in both the near-and long-term;
Acknowledging: The need to continue the extensive existing efforts to enhance the worldwide availability of vital information about the global environment, especially through monitoring, service, and commission-focused research efforts and activities;

Noting: The increasing world-wide occurrence and intensities of environmental problems and the disruptions to overall economic well-being and development that have been and could be caused by natural hazards and extremes and the need to be prepared for the increasing potential for new threats to emerge;

Urges: National and scientific leaders of all nations to recognize the substantial benefits to overall well-being and economic progress, both nationally and globally, that will accrue through advancing scientific understanding of and capabilities for predicting potentially disruptive environmental consequences and extremes; National and scientific leaders of all nations to support the active participation of the members of their scientific community in the collective international effort being undertaken by the IUGG and associated scientific unions within ICSU to strengthen and apply research capabilities and findings for public and general economic benefit and the coordination activities necessary to accomplish such efforts; Scientists and experts around the world to re-dedicate their efforts better to understand the Earth system and, in this time of increasing stress on the global environment, to make their findings available to the public in the most useful and appropriate ways;

Resolves: To be steadfast in: (1) encouraging and supporting the participation of scientists in international scientific meetings and activities, (2) undertaking efforts to enhance fundamental understanding of geophysical processes and behavior, especially in the grand challenge areas, (3) increasing efforts to utilize scientific understanding for the benefit of society and the environment and for promotion of the economy and societal resilience; and (4) in providing an independent voice in support of undertaking and relying on the most rigorous and well-tested scientific findings. 